\title{
CAREERS
}

COLLABORATION US-UK initiative will fund projects in emerging nations p.117
BESEARCH IMPACT Size doesn't matter when it comes to the impact of grants $\mathbf{p . 1 1 7}$
NATUREJOBS For the latest career listings and advice www.naturejobs.com

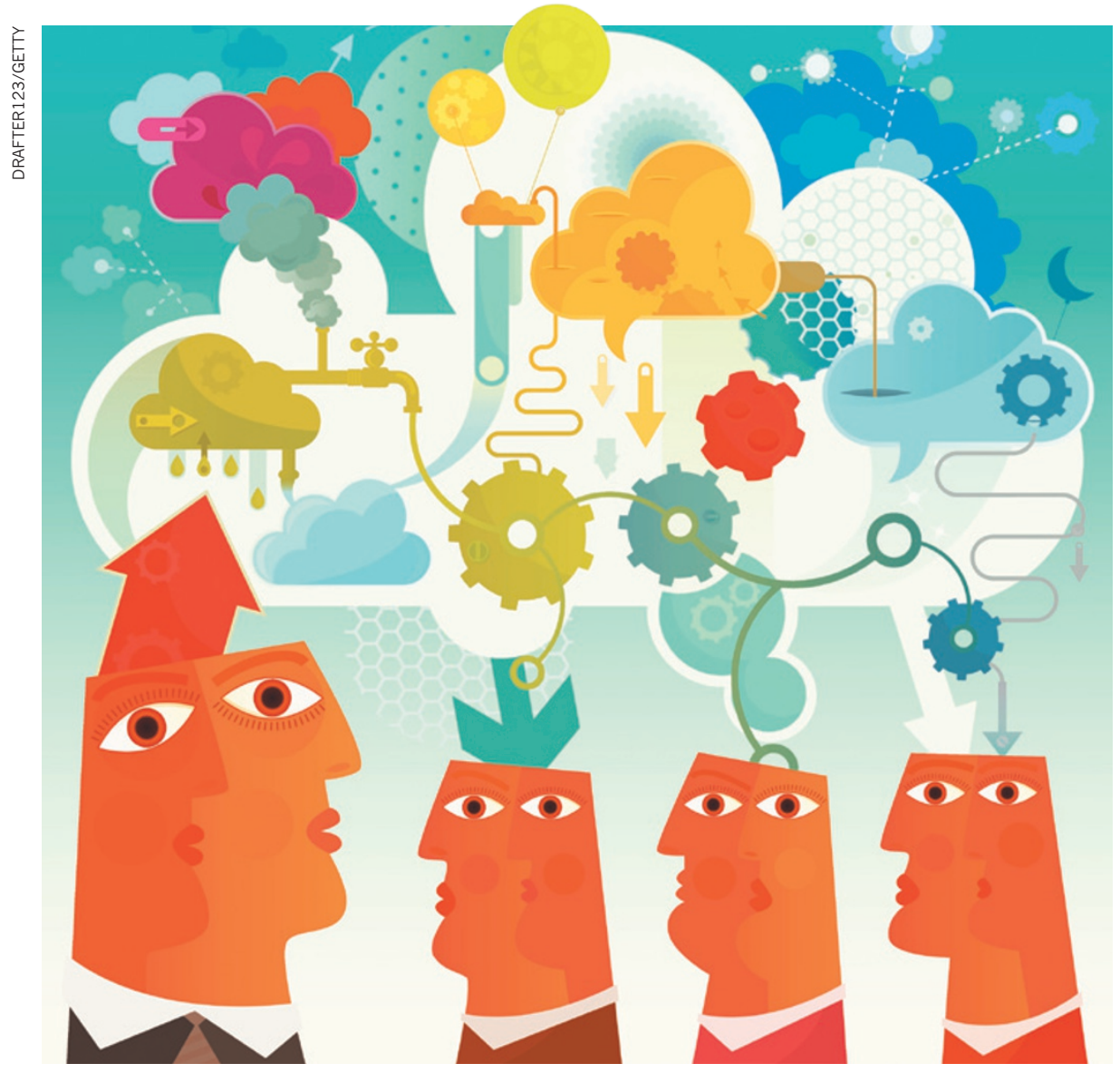

COLLABORATION

\section{A problem shared}

\section{Graduate students often work alone, but programmes exist to teach them how to work towards publication in teams.}

\section{BY CAMERON WALKER}

A t 4 p.m. one spring Tuesday, nine graduate students at Oregon State University (OSU) in Corvallis kick their research into gear. For more than an hour, they discuss their work on fisheries along the US west coast, moving from how data on marine biodiversity hotspots change over time to how to organize tables for a paper.

These students, who have been meeting frequently for nearly two years, are part of the Dimensions of Biodiversity Distributed
Graduate Seminar (DBDGS), a programme that ultimately included teams at 14 institutions - nine in the United States, two in Kenya and one each in Chile, Brazil and China. Each institution's group runs at least one research project, in which students, usually working outside their main field, make intensive examinations of large, mostly pre-existing biodiversity data sets. They formulate research questions, analyse data and publish the results - sometimes in multiple papers, and usually with every student in the group as a co-author. They use the DBDGS network to talk about their work with students at other institutions, share strategies and form collaborations.

Whereas most established faculty members spend ample time collaborating with colleagues, graduate students are often required to toil alone, notes Julia Parrish, a biologist at the University of Washington in Seattle and principal investigator on the three-year, US\$1.5-million US National Science Foundation (NSF) grant that funded the DBDGS. But that means "training people to be last century's scientists", she says. By contrast, collaborative seminars teach students how to work together in a way that is reflective of the contemporary research world.

The distributed-seminar model originated at the US National Center for Ecological Analysis and Synthesis (NCEAS), a research centre of the University of California, Santa Barbara (UCSB), where, in 1997, graduate students from eight institutions first came together to analyse the science of different habitat-conservation plans and create a report. The DBDGS, which launched in 2011 with a pilot project at the University of Washington and is funded until the end of this year, is based on that template. Teams at each institution sent student and faculty representatives to five in-person meetings in Washington state throughout the programme - the largest, in February 2012, brought together close to 60 participants from 14 institutions. Team members learned about each other's work, shared the data that they would use, discussed how they would approach their projects and made connections for future collaborations. Student teams are now working on almost 30 papers; two have been published.

Each team functions as an independent unit, with between 5 and 15 students working together and one or more faculty members offering guidance. Most of the students have an interest in biodiversity, but do not necessarily possess any training in the field that the project covers. At OSU, for example, students with backgrounds ranging from stream ecology to geosciences worked on fisheries data.

\section{LONELY PURSUIT}

The road to publication can be arduous, and programmes that bring graduate students together may help them to avoid pitfalls and stay competitive. The seminars teach $\mathrm{PhD}$ students how to find out what gaps exist in their fields, what methods they could use to analyse their own data, what data sets are already available to work with, how to structure their writing and which journals would be receptive 
to a particular kind of paper.

Graduate students on the DBDGS team at the Virginia Institute of Marine Science (VIMS) in Gloucester Point, part of the College of William and Mary, read research on fish diversity before diving into records of trawling in nearby Chesapeake Bay and measuring specimens in the collection of the Smithsonian Institution National Museum of Natural History in Washington DC. That showed them what ground had already been covered on the subject, says Jonathan Lefcheck, a graduate student in marine community ecology who led the team, and demonstrated "where the gaps were, so we set ourselves up to have a marketable product". The researchers also learned analysis methods and found appropriate citations in the literature, which they intend to use in a paper.

By looking at how previous studies were conducted, students could begin to consider how to analyse their own data sets. In some cases, DBDGS students already had experience with evaluating data, and could split up the workload according to their strengths: one student sequencing fish genes, another doing statistics.

The combined effort made it possible to tackle data sets that would overwhelm a single student, or even an individual lab. In the course of a year, the team at UCSB compiled global fisheries data from eight or nine sources - a project that few, if any, of the students would have pursued for their own dissertations, says Laura Dee, a graduate student in conservation and marine ecology at UCSB who led one of the teams.

Lefcheck taught himself new methods, from multivariate statistics to building evolutionary trees, which he would not have attempted without the backing of the group. "If it became too much of a burden, I could ask others to pitch in," he says. Going beyond his own dissertation work, Lefcheck read primary literature and contacted authors as well as students and faculty members in the wider DBDGS network. He is now applying many of these methods to his dissertation work.

For many students, the writing process

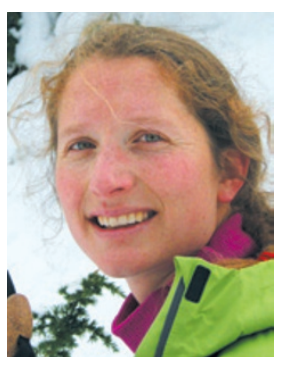

"Really open conversations and transparency from the beginning are the way to go." Ailene Ettinger

itself is daunting. Some DBDGS students went on programme-sponsored writing retreats to help them tackle the process. At one, students and faculty members on the University of Washington team collaborated on a draft of a paper abstract and introduction - one person wrote for two minutes, then passed the piece of paper to the next person. "It helped us relax a little bit, and just get into the writing mode," says Ailene Ettinger, a biology graduate student who co-led the team.

The OSU team broke into two groups, each working on a paper using the same data. One used a traditional approach, dividing the paper into sections for one or two students to tackle, with the team leader pulling them together. Students in the other group went to their retreat with sections that they had already written separately. They assembled the paper as a group, using a projector to put it up on the wall and edit it line by line. "Having everyone in one place may have actually sped things up a bit," says Selina Heppell, a marine fisheries ecologist at OSU and the team's faculty adviser. Institutions may also offer one-off presentations from editors of scientific journals, who can provide insight into the publishing process.

\section{WORKING TOGETHER}

Throughout the DBDGS programme, students constantly practised how to interact with other researchers - whether explaining their work or negotiating how to distribute tasks - while keeping everyone on track to publication.

Determining who gets credit for what when it comes to authorship is often difficult (see Nature 489, 591-593; 2012). During the DBDGS, for example, each group had to come to a consensus about what to do if people dropped out. The OSU team decided that anyone who stuck with and contributed to the project for the entire first year would be an author. Even though the students split into two groups, Heppell says, all have contributed something substantial to the work as a whole - and each of the 14 students will be on the seminar's two papers.

The University of Washington group decided to wait until it was most of the way through the data analysis before it chose a lead author. In the end, two students were designated joint leads, and flipped a coin to see whose name would be listed first. "Really open conversations and transparency from the beginning are the way to go, so that everyone knows what the expectations are," says Ettinger.

Cross-disciplinary collaborations have emerged between institutional teams. Parrish recalls that when students from UCSB and OSU first met, they were unsure of each other. The Oregon team was looking at what species came up in individual trawls in a single stretch of the Pacific Ocean; the Santa Barbara students were poring over global fisheries data from a conservation angle. As they discussed their projects, however, they realized that combining the scales could yield interesting results. Now students from the teams are at work on an independent project - a collaboration that Kate Boersma, a graduate student in stream ecology at OSU, calls the most rewarding aspect of the programme. It has influenced her dissertation research, and she hopes that its effects will continue after she graduates.

Parrish says that some of the international 


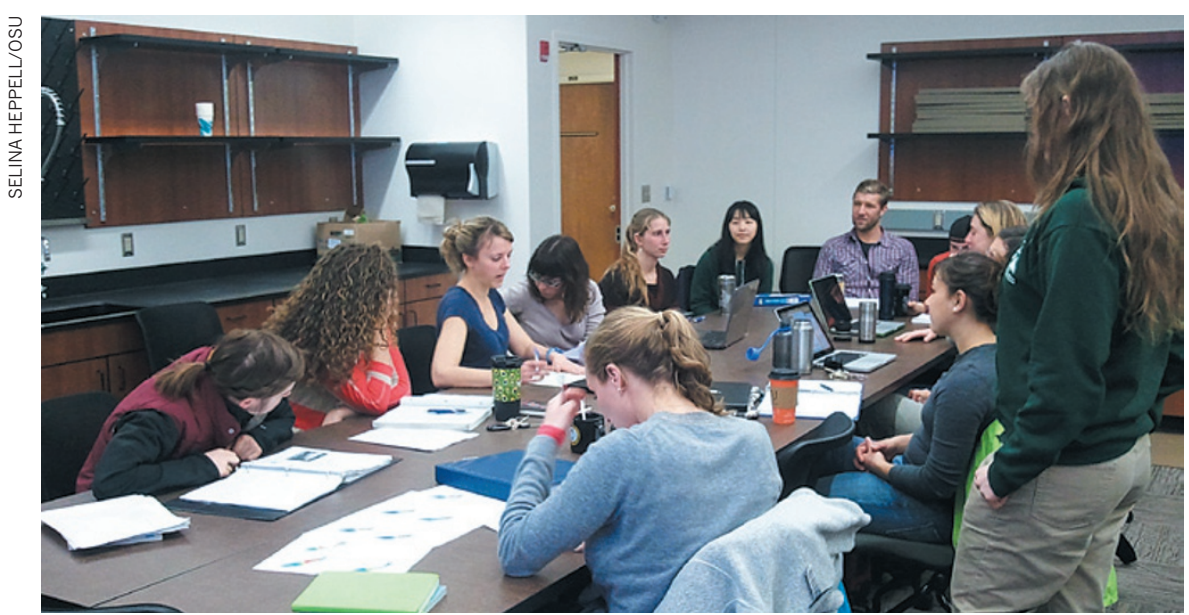

A seminar team at Oregon State University works through the trials of collaboration.

groups have struggled because of funding, travel or infrastructure difficulties at home. However, the team at the Federal University of Rio Grande do Sul in Porto Alegre, Brazil, has thrived: taking advantage of their strong backgrounds in statistics and mathematics, its students have published a paper.

Graduate student Vanessa Weinberger, a team leader at the Pontifical Catholic University of Chile in Santiago, says that she has benefited from working with a large team of people who do not share her background in theoretical ecology, and from the opportunity to present research in English. In Chile, she says, it is relatively unusual for graduate students from different laboratories - let alone different universities - to collaborate on a project outside their theses.

\section{BRANCHING OUT}

The DBDGS is set to end this year, but George Gilchrist, an NSF programme director, says that its good results have prompted the foundation to consider repeating the exercise. The NCEAS would also be open to hosting further distributed seminars, says deputy director Stephanie Hampton. The centre is currently hosting its first three-week institute for earlycareer researchers, which had more than 400 applicants from around the world. The 22 successful participants, including several graduate students, are learning skills for collaborative, data-intensive ecological research. The programme runs from 19 June to 10 July, and the NCEAS plans to offer it each year.

With a colleague, Helene Wagner, a landscape ecologist at the University of Toronto Mississauga in Canada, has led two landscape-genetics courses based on the distributed-seminar model. Students could opt to participate in group projects using existing data sets and simulation studies. The first, conducted in person and online in 2010, resulted in five papers. Unlike the mostly single-institution DBDGS groups, each team was made up of a mix of students from the 15 participating universities in North
America and Europe, including the Swiss Federal Institute of Technology in Zurich and Joseph Fourier University in Grenoble, France. The second course took place entirely online, mitigating student travel expenses; even students who were not at a participating institution could sign up. A similar course is planned for 2014.

In the United Kingdom, Vitae, a Cambridge-based organization that focuses on researchers' professional development, has offered publishing workshops with Macmillan Science Communication in London (which has the same parent company as Nature). It also runs a course called The Collaborative Researcher, which brings together 40 researchers at a time to learn skills including communication, cultural awareness, planning and negotiation.

\section{SIDE PROJECTS}

Seminars such as these take up precious time, which is often in short supply for graduate students. Dee extols the skills and collaborations that she has gained from the DBDGS - but says that the process took longer than anyone expected. She estimates that it delayed her thesis by four months. But her $\mathrm{CV}$, she hopes, will boast papers from both the seminar and her cross-seminar collaborations - and some of the work that she is doing with OSU students will be part of her dissertation.

Heppell told students in her team - particularly those who signed up to tackle big workloads, such as data analysis - that they needed to have a serious talk with their advisers about how much time it would take. She has not heard any complaints; in fact, advisers have commented that if students get publications, the DBDGS is a good use of their time. "I think advisers realize that the stakes are higher now," she says, referring to research funding challenges. "The jobs are fewer." -

Cameron Walker is a freelance writer based in Santa Barbara, California.

\section{COLLABORATION}

\section{US and UK join forces}

The United States and Britain are launching a global research collaboration to address issues such as water supply and climate change in emerging nations. The 5 -year programme will fund up to a total of 40 US and UK grants per year, says Richard Everitt, deputy director of the British Council USA in Washington DC. He did not disclose amounts but said that awards could last for up to three years. Funding will come from the British Council, the UK Department for Business, Innovation and Skills and the US Department of State. "We want to create a cadre of young researchers who can work with their counterparts from the emerging world," says Everitt. The initiative will form partnerships with universities in nations such as China, Brazil, India and Indonesia, and will seek grant proposals in September.

\section{RESEARCH IMPACT}

\section{Bang not based on buck}

Grant size does not strongly predict scientific impact, according to a study published in PLOS ONE. The authors used four measures - publications, citations, highly cited papers and citations of the most-highly cited paper - to score the impact of 374 researchers funded between 2002 and 2006 by the Natural Sciences and Engineering Research Council of Canada. Grant sizes explained less than 30\% of the variation (J.-M. Fortin and D. J. Currie PLOS ONE 8, e65263; 2013). Co-author David Currie, a biologist at the University of Ottawa, says, "Some very poorly funded people manage to do a great deal."

\section{UNITED KINGDOM}

\section{Funding freeze critiqued}

A UK science-advocacy group says that a repeated freeze to the government's $£ 4$-6-billion (US\$7-billion) scienceresearch budget, announced on 26 June, will damage early-career researchers' work and drive them to other nations. Science is Vital, formed to track the results of a 2010 budget freeze, polled 868 UK researchers, and found that $70 \%$ of junior scientists have lost confidence in research careers in Britain. Some $59 \%$ of respondents applying for grants said their success rate had fallen; $39 \%$ of those with labs have recruited fewer PhD students and 19\% could not recruit any. "Frustrated young researchers are leaving," says Jennifer Rohn, chair of Science is Vital and a cell biologist at University College London. 